ни в системі вищої військової освіти, перш за все щодо модернізації змісту і технологій навчання.

3. Запропонована у процесі роботи компетентнісна модель може бути взята за основу при підготовці спеціалістів військового перекладу.

4. Реалізація запропонованої в роботі компете- нтнісної моделі вимагає відповідних управлінських рішень щодо подальших дій командного і викладацького складу вищих військових навчальних закладів України направлених на отримання позитивного результату в процесі надання якісних освітніх послуг в системі вищої професійної освіти.

\title{
Література
} 19832

1. Указ Президента України від 14 березня 2016 року № 92/2016. URL: http://www.president.gov.ua/documents/922016-

2. Положення про Методичну раду Національної академії Національної гвардії України. Х.: Національна академія Національної гвардії України, 2014.

3. Соколовський В. В. Характерні риси особистості курсантів та особливості їх навчання у вищих військових навчальних закладах системи МВС України // Засоби навчальної та науково-дослідної роботи. 2011. Вип. 35. С. $158-164$.

4. Іщенко А. О. Педагогічні умови формування готовності майбутніх офіцерів до виховної роботи з особовим складом // Науковий огляд. 2015. № 7 (17). С. 73-82.

5. Освіта в Україні. URL: http://www.education.ua

6. Про затвердження Національної рамки кваліфікацій. Постанова Кабінету Міністрів України від 23 листопада 2011 p. № 1341. URL: http://zakon.rada.gov.ua/laws/show/1341-2011-\%D0\%BF

7. Лунячек В. Е. Оцінювання результатів професійної підготовки керівних кадрів в умовах магістратури до управління якістю освіти // Наша школа. 2012. № 1. С. 14-21.

8. Положення про організацію освітнього процесу в Національній академії Національної гвардії України. Х.: Національна академія Національної гвардії України, 2014.

9. Пометун О. Компетентнісний підхід - найважливіший орієнтир сучасної освіти // Рідна школа. 2005. № 1. С. 65-69.

10. Прахова М. Ю., Заиченко Н. В., Краснов А. Н. Оценка сформированности профессиональных компетенций // Высшее образование в России. 2015. № 2. С. 21-27.

Рекомендовано до публікачії д-р пед. наук, професор Лунячек В. Е. Дата надходження рукопису 26.07.2018

Посохов Віталій Васильович, старший викладач, кафедра експлуатації та ремонту автомобілів та бойових машин, Національна академія Національної гвардії України, майдан Захисників України, 3, м. Харків, Україна, 61001,

E-mail: posohovv@ukr.net

Куруч Анна Володимирівна, кафедра педагогіки та інтелектуальної власності, Українська інженернопедагогічна академія, вул. Університетська, 16, м. Харків, Україна, 61003,

E-mail: Anutakuruch@ukr.net

\author{
УДК 378.14:504
}

DOI: $10.15587 / 2519-4984.2018 .142019$

\section{DEVELOPMENT MODEL OF PROFESSIONAL COMPETENCES IN ENVIRONMENTAL MONITORING IN THE SYSTEM OF POSTGRADUATE EDUCATION}

\section{(C) N. Bordiug, N. Ridei}

Під час дослідження розроблено структурно-функціональну модель формування професійних компетентностей у системі післядипломної освіти та визначено ї̈ основні компоненти (цільовий, концептуальний, змістовний, операційний і діяльнісний, контрольний і регулятивний, результативний $і$ діагностичний). Дана модель є узагальненою системою зі системно-інновачійним підходом до вдосконалення теоретичних знань і практичних умінь у галузі моніторингу довкілля, щуо відображає змістовну наповнюваність професійного розвитку фахівців, основні науково-методологічні положення (принципи, явища, прочеси), які можуть бути скориговані відповідно до конкретних вимог професійної діяльності фахівців природоохоронної галузі. Виокремлено складові підготовки фахівия з моніторингу довкілля: спеціальна $і$ професійна (інформачійна, графічна, професійно-мотивачійна, гностична, комунікативна, адаптивна), наукова і дослідницька (методологічна, аналітична, прогностична) та лабораторна і практична (методична, організачійна, діяльнісна), які взаємодоповнюють одна одну та тісно взаємопов 'язані. Охарактеризовано кожний компонент структурно-функціональної моделі та показано взаємозв'язки між ними. Показано, методику формування професійних компетентностей з моніторингу довкілля у системі післядипломної освіти. Встановлено, щчо дана модель структурує та удосконалює етапи формування професійних компетентностей у фахівців з екології, визначає організаційно-педагогічні умови даного проце- 
су. Зокрема, удосконалення змістовного компонента, комплексне поєднання різних форм організації навчання, створення інноваџійно-освітнього середовищза з моніторингу довкілля у системі післядипломноі освіти. За даною моделлю професійні компетентності з моніторингу довкілля будуть розвивати працівники державних, експертно-контрольних, інспекційних,відомчих, наукових і освітніх, суспільних інституцій, виробничих, природоохоронних, підприємств, установ, інституцій, громадських організацій Ключові слова: моніторинг довкілля, післядипломна освіта, модель, професійні компетентності, фахівиі з екологї, принциии навчання

\section{Introduction}

Requirements of the modern society motivate specialists to the continuous self-improvement and development of professional competences that condition their demand for different forms of adult education. It concerns also specialists of the ecological direction, because there takes place the fast renovation of modern scientific knowledge in the ecological branch, especially as to the methodology of organization and realization of environmental monitoring in the context of the sustainable development strategy. So, it is necessary to elaborate a model of professional competences formation in ecological specialists at different stages of the National qualification frame in the system of higher and postgraduate education.

\section{Literary review}

We used elements of pedagogical modeling at constructing the model. Pedagogy investigated theoretical aspects of modeling [1, 2], use of modeling methods at higher school [3]. The method of pedagogical modeling is widely used for studying processes and phenomena, properties of objects, establishing dependencies between all components of the learning-cognitive activity $[4,5]$.

Modeling is a base of the system analysis of the studied problem, because it is possible to study the educational process completely and to separate all components of it [6]. Other authors think that this approach helps to prevent negative scenarios due to prognostication of the development of separate processes in the system [7].

The literature widely elucidates the problem of postgraduate ecological education of teachers [8], formation of the ecological competence in schoolchildren [9], problem of ecological education and upbringing in future specialists [10].

The problem of the professional competences development in environmental monitoring in the system of postgraduate education is left beyond scientists' attention. So, there is a necessity in investigating the content and methodological support of training ecological specialists in the system of postgraduate education and elaboration of a structural-functional model of their professional development.

\section{Aim and tasks of the research}

The aim of the research - is to define components of the structural-functional model of the development of professional competences in environmental monitoring in ecological specialists.
The following tasks were set for attaining this aim:

1) To elaborate the structural-functional model of the development of professional competences in environmental monitoring;

2) to determine organizational-pedagogical conditions of the professional competences development in specialists of the nature protection branch;

3) to characterize main stages and structural components of the model.

4. Peculiarities of the structural-functional model of the professional competences development in environmental monitoring

Modeling of the system of formation of professional competences in ecological specialists is conditioned by the complexity and numerous aspects of the system, separation of main components in it, establishment of the whole totality of interconnections, investigation of characteristics of both separate elements and system as a whole, obtaining of new scientific-pedagogical and methodological knowledge as to organization and functioning of this system.

The structural-functional model of the professional competences development in environmental monitoring in ecological specialists is a generalized system with a system-innovative approach to improving theoretical knowledge and practical skills in the field of environmental monitoring, especially monitoring of stability and development of systems (fig. 1).

The aim component is system-creating, because all system components are directed on attaining the aim, namely development of professional competences in ecological specialists according to demands of labor and social market for improving their professional activity. Tasks of the professional development of nature protection specialists in the system of postgraduate education are: to develop professional competences in environmental monitoring; to separate personal-professional qualities to motivate to self-development and self-improvement in the professional activity during the whole life.

The structural-functional model is complex, because it contains the main stages of the professional competences development in environmental monitoring in the system of post-graduate education - improvement of professional competences at improving the qualification, probation, retraining nature protection specialists, especially at studying the special course "Monitoring of sustainable development" with the nature protection and nature resource, theoretical methodological, analyticalprognosticating background and also acquiring scientific degrees. 


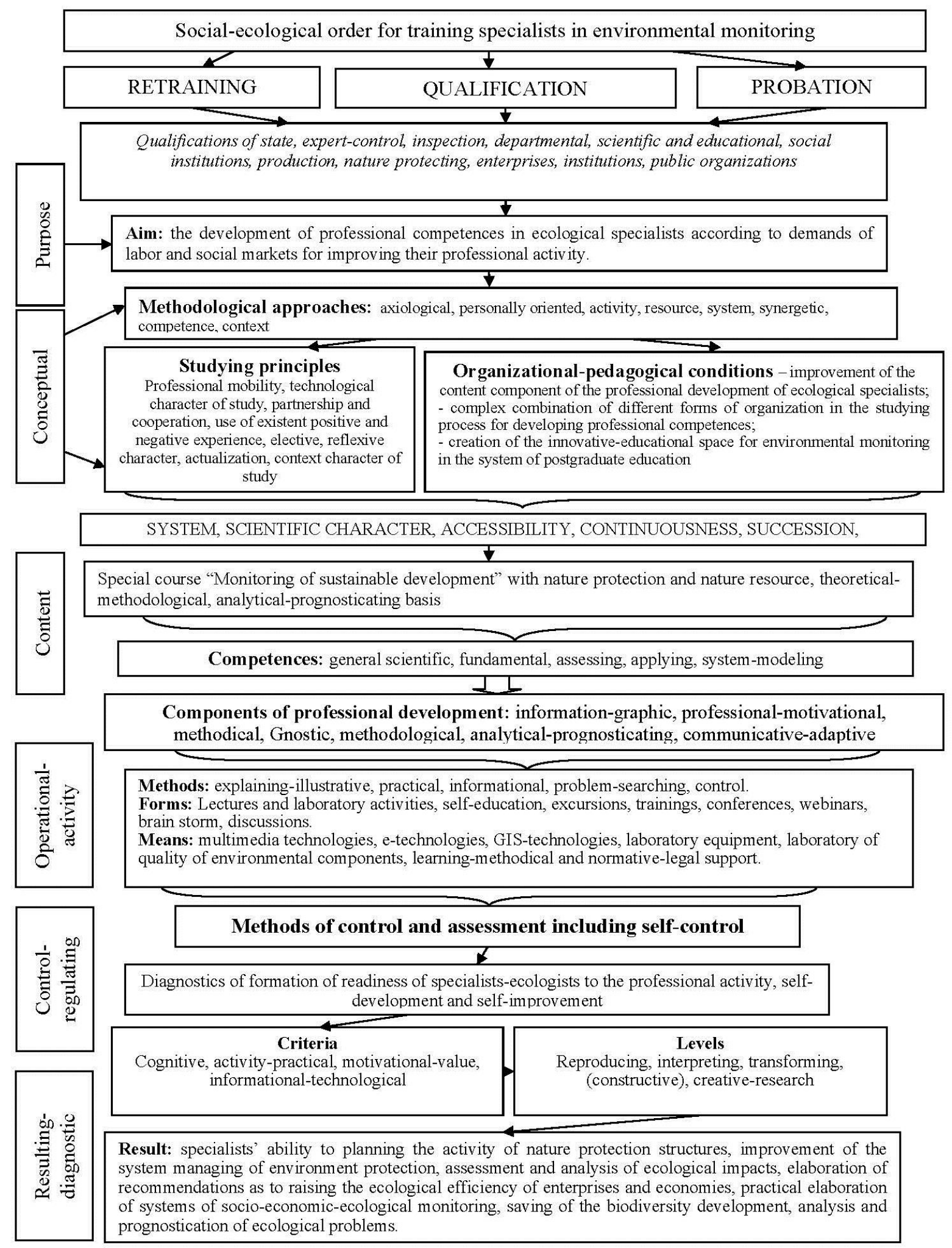

Fig. 1. Model of the professional competences development in environmental monitoring

The success of realization of the model in the system of postgraduate education is determined by organizational-pedagogical conditions:

1) improvement of the content component of the professional development of ecological specialists;
2) complex combination of different forms of organization in the studying process for developing professional competences;

3) creation of innovative-educational space of environmental monitoring in the system of postgraduate education. 
Specialists of the nature protection branch that work by different qualifications (state, expert-control, inspection, departmental, scientific and educational, social institutions, production, nature protecting, enterprises, institutions, public organizations) have already acquired practical experience and improve their professional competences in the system of post-graduate education.

\section{Research results and their discussion}

The elaborated model is internally-organized and functional-activity, and contains main components: purpose, conceptual, content, operational-activity, controlregulative, resulting-diagnostic.

1. Purpose - determines the practical directionality of ecological specialists' activity in environmental monitoring.

The purpose component is directed on training, retraining and qualification improvement of ecological specialists in environmental monitoring and provides conditions for personal self-realization, revelation of talents and inclinations, formation of professional competences, especially, ability to solving complecated ecological situations by non-standard and operative methods, to professional mobility. This component is systemcreating, because all other ones of the model are directed on attaining the aim - training of a competent, mobile, competitive specialist with personal and professional values, deep theoretical-fundamental and professionalpractical knowledge, skills and abilities, able to solve complicated ecological problems. For forming the aim, the modern labor market was analyzed, the low professional activity and motivation to the work among specialists-ecologists was revealed.

The main aim of the system of postgraduate education is to form the motivation to self-education, selfdevelopment and self-improvement in ecological specialists that in further determines the method of improving professional competences in environmental monitoring.

2. Conceptual - determines theoreticalmethodological approaches (personal-activity, synergetic, system, integration) and scientific-pedagogical principles of study that provide the effectiveness of improving professional competences in environmental monitoring in ecological specialists.

3. Content - content and components of training of ecological specialists up to the development of professional competences as a base of the complex program elaboration.

The content component provides acquiring base special (professional) and scientific knowledge in environmental monitoring, on which base general scientific, fundamental, assessing, applying, system-modeling competences and also ability to self-development and selfimprovement are formed in specialists. We separated components of training a specialist in environmental monitoring: special and professional (informational, graphic, professional-motivational, gnostic, communicative-adaptive), scientific and research (methodological, analytic, prognostic), laboratory and practical (methodical, organizational, activity) that mutually add each other and are closely connected.

4. Operational-activity - methods, forms and means of training ecological specialists.
The use of methods, forms and means depending on an educational level help to master theoreticalpractical and scientific research knowledge, to improve abilities and skills to self-education and selfdevelopment, use of the system approach in the professional activity, striving for acquiring theoreticalfundamental and analytical-prognostic knowledge. The system of postgraduate education contains explainingillustrative, practical, information, problem-searching, control studying methods; Forms - lectures and laboratory activities, self-education, excursions, trainings, conferences, webinars, brain storm, discussions; means multimedia technologies, e-technologies, GIStechnologies, laboratory equipment, laboratory of quality of environmental components, learning-methodical and normative-legal support.

5. Control-regulative - teacher's control over set studying tasks, self-control over correctness of making tasks at all stages of professional competences formation and realizes the direct influence on all components of the model of the studying system of environmental monitoring. This component is directed on diagnosing the ecological specialists' readiness to the professional activity in environmental monitoring, inspection and correction of mastering of elements of the content component.

6. Resulting-diagnostic - assessment of the effectiveness of functioning of the model at the expanse of checking formation levels of educational competences. The main criteria of the resulting-diagnostic component are cognitive (quality, content and volume of acquired knowledge); activity-practical (formed abilities and skills that specialists are able to use and develop in the practical sphere); motivational-value (motivation to selfstudying, self-development, self-improvement, acquiring of personal-professional qualities); informationtechnological.

As a result nature protection specialists' ability to planning the activity of nature protection structures, improvement of the system managing of environment protection, assessment and analysis of ecological impacts, elaboration of recommendations as to raising the ecological efficiency of enterprises and economies, practical elaboration of systems of socio-economic-ecological monitoring, saving of the biodiversity development, analysis and prognostication of ecological problems develop.

The elaborated structural-functional model is a system that reflects the content filling of training ecological specialists, main scientific-methodological statements (principles, phenomena, processes) that may be corrected, corresponding to concrete requirements of the professional activity of specialists-ecologists and also to the future development in the spheres of education and ecology.

\section{Conclusions}

1. The structural-functional model of the professional competences development of environmental monitoring in ecological specialists is realized through the purpose, conceptual, content, operational-activity, control-regulating, resulting-diagnostic components and connections between them.

2. It was established, that this model structures and improves formation stages of professional compe- 
tences in ecological specialists, determines organizational-pedagogic conditions of this process.

3 . There was studied the method of formation professional competences of environmental monitoring in the system of postgraduate education through studying principles, content filling, methods, forms and studying means, diagnostics of knowledge, abilities and skills that in the final result will form a high-qualified specialist, able to solve complicated ecological problems in the professional activity.

\section{References}

1. Mikheev V. I. Modelirovanie i metody teorii izmereniy v pedagogike. Moscow: KomKniga, 2006. 200 p.

2. Pirogova O. V. Modelirovanie v obrazovanii // Innovatsii v obrazovanii. 2004. Issue 5. P. 36-40.

3. Vashchyk T. I. Modeliuvannia u navchalno-vykhovnomu protsesi vyshchoi pedahohichnoi shkoly // Novi tekhnolohii navchannia. 2005. Issue 41. P. 147-158.

4. Riznyk O. Ia. Lohichne prohramuvannia: textbook. Lviv: Vyd-vo NU «Lvivska politekhnika», 2008. 332 p.

5. Fitsula M. M. Pedahohika: textbook. Kyiv: Akademvydav, 2009. 560 p.

6. Shamova T. I., Davydenko T. M. Upravlenie obrazovatel'nym protsessom v adaptivnoy shkole. Moscow: Pedagogicheskiy poisk, 2001. $384 \mathrm{p}$.

7. Kharbatovych S. V. Teoretychni aspekty modeliuvannia yak metodu naukovoho doslidzhennia // Visnyk Chernihivskoho natsionalnoho pedahohichnoho universytetu. 2012. Issue 96. P. 184-188.

8. Melnychenko R. K., Tanska V. V. Ekolohichna kompetentnist vchytelia yak peredumova zdiisnennia neperervnoi ekolohichnoi osvity i vykhovannia // Naukovi zapysky KDPU. Seriia: Problemy metodyky fizyko-matematychnoi i tekhnolohichnoi osvity. 2013. Issue 4 (2). P. 271-275.

9. Formuvannia ekolohichnoi kompetentnosti shkoliariv: nauk.-metod. posibnyk / N.A. Pustovit, O.L. Prutsakova ta in. Kyiv: Pedahohichna dumka, 2008. $64 \mathrm{p}$.

10. Biletska H. A. Tendentsii i problemy rozvytku ekolohichnoi osvity // Suchasni informatsiini tekhnolohii ta innovatsiini metodyky navchannia v pidhotovtsi fakhivtsiv: metodolohiia, teoriia, dosvid, problemy. 2012. Issue 30. P. 300-306.

Дата надходження рукопису 06.08.2018

Natalia Bordiug, PhD, Associate Professor, Department of Environmental Safety and Natural Resources Management, Zhytomyr National Agroecological University, Staryi blvd., 7, Zhytomyr, Ukraine, 10008

E-mail: natali-21@ukr.net

Nataliia Ridei, Doctor of Pedagogical Sciences, Professor, Department of Adult Education, National Pedagogical Dragomanov University, Pirogova str., 9, Kyiv, Ukraine, 01601

E-mail: nataliia.ridei@gmail.com 